\title{
An experimental and field investigation study on geotechnical characterisation and stability assessment of Surbhi Resort landslide at Mussoorie, India
}

B Venkateswarlu ( $\sim$ bvenkatiitd@gmail.com )

Indian Institute of Technology Roorkee

Mahendra Singh

Indian Institute of Technology Roorkee

\section{Research Article}

Keywords: landslide, GPR, shear strength, RMR, Q, GSI, slope stability

Posted Date: February 2nd, 2022

DOI: https://doi.org/10.21203/rs.3.rs-1236161/v1

License: (c) (i) This work is licensed under a Creative Commons Attribution 4.0 International License.

Read Full License 


\title{
An experimental and field investigation study on geotechnical characterisation and stability assessment of Surbhi Resort landslide at Mussoorie, India
}

\author{
B Venkateswarlu ${ }^{1, *}$ and Mahendra Singh ${ }^{2}$ \\ ${ }^{1}$ e-mail:bvenkatiitd@gmail.com, Research scholar, Dept. of civil engg., IIT-Roorkee, Roorkee, India \\ ${ }^{2}$ e-mail:msingh.civil@gmail.com, Professor, Dept. of civil engg., IIT-Roorkee, Roorkee, India
}

\begin{abstract}
Landslides occur frequently in the Himalayan region, especially during the monsoon season. Stability assessment of any landslide site provides a good understanding of the shear-strength response of the in-situ geomaterials and causative factors. Often the sliding geomaterial is a complex mixture of soil and rock pieces in the form of debris underlain by jointed rock strata (bedrock). Testing of these materials in the undisturbed state is generally not feasible, and hence, the shear-strength parameters are derived through simple field investigation, index testing and classification. In the present study, a methodical procedure involving field investigations and laboratory studies was adopted to carry out stability assessment of a landslide site in the Lesser Himalayan region. The field investigations included a ground-penetrating radar (GPR) study, mapping of joints in the rock mass and collection of debris and rock samples. Apart from it, laboratory studies included an X-ray diffraction (XRD) analysis of the sand-fines matrix, index testing of soil samples, direct shear tests on debris samples and point-load strength-index testing on rock chunks. Laboratory tests were performed using conventional triaxial and a state-of-the art large-sized direct shear experiments. For large-sized direct shear testing, the gravel fraction was varied to quantify the effect of gravel content on the internal friction angle $(\phi)$. The parameter, cohesion of the debris was derived through back-analysis method. The rock mass rating (RMR), tunnelling quality index (the Q-system) and the geological strength index (GSI) were used to characterise the rock mass whereas, the shear strength parameters of the rock mass were derived through two non-linear strength criteria. Initial estimates of the shear-strength parameters of debris and the rock mass were employed to obtain the factor of safety (FOS) of the slope, which was found to have been underestimated. Back-analysis was then used to adjust the shear-strength parameter for cohesion. These adjusted parameters were then used to assess the stability of the slope and to suggest remedial measures.
\end{abstract}

Keywords: landslide, GPR, shear strength, RMR, Q, GSI, slope stability. 


\section{INTRODUCTION}

A landslide is defined as the downward and outward movement of slope-forming materials that include soil, debris, fractured rocks or a combination of these (Varnes 1958). The Lesser Himalayan belt is characterised by rugged topography with extensively elevated hills, debris deposits and deep ravines (Siddique \& Pradhan 2018), as well as fractured, folded and faulted rocks (Malik and Mohanty 2007). Landslides are very common in this region, especially during the monsoon season. Geomaterial encountered at a landslide site generally comprises of a debris layer underlain by jointed rock strata. Slope failure may occur either in debris or through the underlying jointed rock mass. Hence, analysis of a landslide site involves a thorough understanding of the geology, as well as the shear strength characteristics of the debris and jointed rock mass.

The debris material encountered at a landslide site exhibits large variations in gravel, sand and fines fractions, while the rock is jointed to different degrees. Since assessment of the shear strength parameters of these geomaterials through laboratory testing in in-situ condition is not feasible, these parameters are commonly derived indirectly with the help of simple index testing in the field and laboratory, and via classification. The rock mass rating (RMR), tunnelling quality index (the Q-system) and geological strength index (GSI) are popular classification systems for characterising jointed rock masses. Non-linear strength criteria are used to define the shear strength of a rock mass. Once the shear strengths of the debris and jointed rock strata have been defined, numerical methods are generally adopted to assess the stability of the slope.

In the present study, the shear-strength parameters of the debris and jointed rock mass were derived and used for the stability analysis. For this, a landslide site from the Lesser Himalayan belt was selected, from which debris and rock chunk samples were collected for laboratory testing. A ground-penetrating radar (GPR) survey and rock joint mapping were conducted in the field. Debris samples were collected and their grain size distribution analysis, X-ray diffraction (XRD) analysis, triaxial and direct shear tests were performed at laboratory. As the gravel content tends to vary widely in the field, large-sized direct shear testing was conducted on debris with varying gravel contents. The shear strength parameters of the debris were finally adjusted through back-analysis. Kinematic and limit equilibrium analyses were performed to assess the stability state of the slope. Non-linear shearstrength criteria were used to assess the shearstrength parameters of the rock mass. The limit equilibrium method was used to assess the stability of the slope and to suggest control measures.

\section{METHODOLOGY}

\subsection{Earlier Studies}

The investigated landslide site is situated on the National Highway NH-92 in Mussoorie, Uttarakhand state, India, at latitude $30^{\circ} 28^{\prime} 56.6 \mathrm{~N}$ and longitude $78^{\circ} 03^{\prime} 02.5$ E near the Surbhi Resort (Fig. 1). The crown of the landslide is located at an elevation of around $1650 \mathrm{~m}$ on the NW-SE trending ridge. The dip direction of the landslide is at around $\mathrm{N} 342^{\circ}$, and the landslide area is a typical example of a debris slide. The main scarp of the slide was identified below the Surbhi Resort. A landslide was initiated as a small scar during the 1991 Uttarkashi earthquake, and later on, a major landslide was triggered in August 1998 due to excessive rainfall and reactivated again after heavy rainfall in July 2003. The results of studies performed by Gupta and Iqrar (2007) and Gupta et al. (2016) indicate that the cause of landslides is incessant rainfall. In the later study, the authors found that the slope is still 
unstable, especially in the crown area of the landslide site. In a preliminary study conducted by the first author of the present paper, the main scarp that developed in 1998 appeared to be stable. However, a new scarp was again observed nearly $200 \mathrm{~m}$ away from the Surbhi Resort (the old and new scarps are shown in Fig. 2).

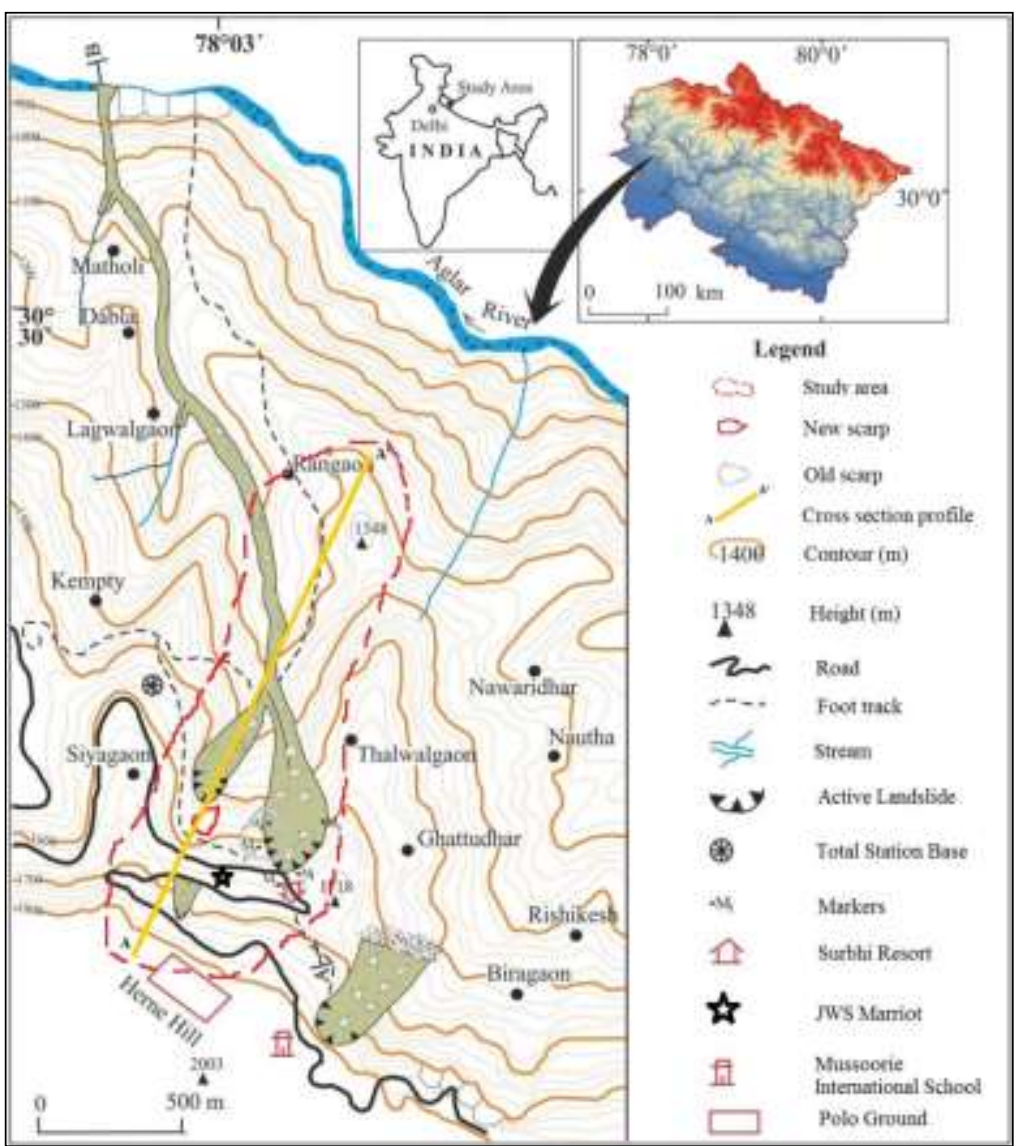

Fig. 1 Location map of the study area (after Gupta and Iqrar 2007).

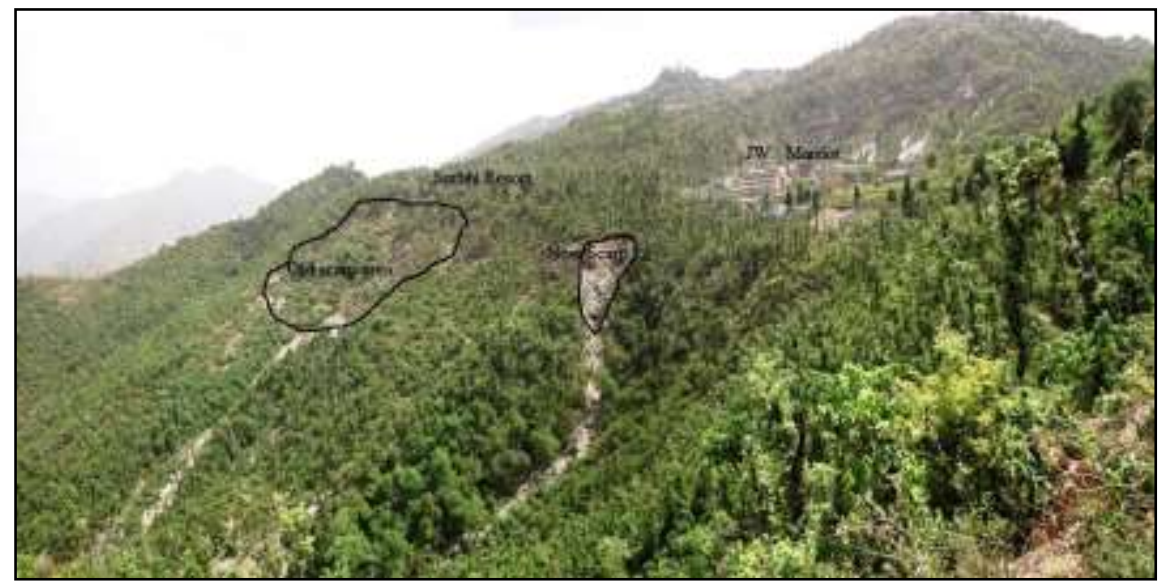

Fig. 2 View of landslide showing old and new scarp in the study area

\subsection{Geology of the Study Area}

The study area lies in the Lesser Himalayan region of the Indian Himalayas. The landslides occurred on the north facing slope of the mountains descending from 2000 to $1000 \mathrm{~m}$ above sea level. The Aglar River, a tributary of the Yamuna River, flows to the west at the base at an elevation of around $800 \mathrm{~m}$ above sea level. Geologically, the 
region forms a part of the main Krol belt, and the regional geology comprises of the Jaunsar-Blaini-Krol-Tal sequence folded in the form of the Mussoorie syncline and thrusts over the Siwaliks in the south along with the Krol thrust. The stratigraphy of the Mussoorie Syncline consists mainly of sedimentary rocks from the Krol belt. The study area falls in the northern limb of the Mussoorie Syncline and is made up of Neoproterozoic shallow-water carbonate sediments belonging to the Krol formation of the Lesser Himalaya (Tewari 2012). The rock type present at the site is mainly intraclastic fractured dolomitic limestone from the Upper Krol that is highly faulted, jointed and fractured (Gupta and Iqrar 2007). The debris material comprises of a mixture of soil, rock particles and boulders of various sizes (Fig. 3a and 3b). The landslide area is approximately 2.96 ha. Fig. 4 shows a cross-sectional profile of the slope drawn along section A-A' in Fig. 1. The average slope angle of the profile (from crown to toe) varies from $35^{\circ}$ to $40^{\circ}$. The average annual rainfall in the area is nearly $2073.3 \mathrm{~mm}$, out of which around $1200 \mathrm{~mm}$ occurs during the rainy season from June to September (Singh et al. 2015; Dudeja et al. 2017).
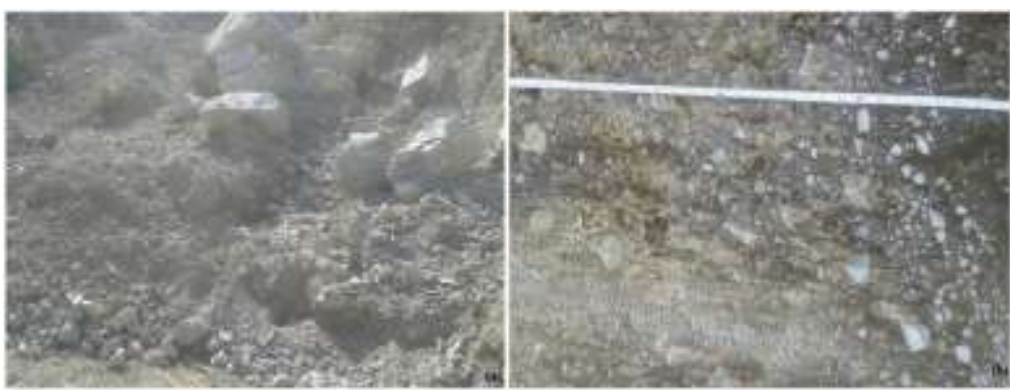

Fig. 3 Geomaterials observed at the toe of the landslide site (a) discrete debris materials with bouldery content (b) alluvial deposits with rock particles

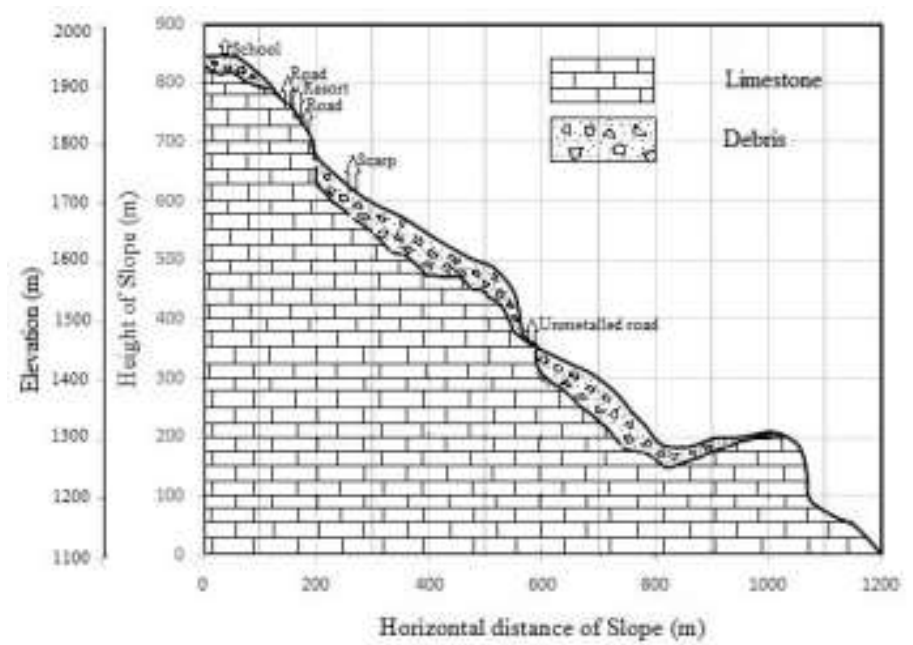

Fig. 4 Cross-sectional profile of the slide (passing through JW Marriot Resort, Mussoorie)

\subsection{Kinematic Analysis of Rock Slope}

Kinematic analysis was performed to assess the probable mode of failure of the rock slope. The slope mass comprises of debris material underlain by jointed rocks, and the stability of the rock slope is governed by characteristics of the structural discontinuities present in rocks. Mapping of the joints at the exposed rock surfaces was carried out. Three sets of joints were observed at the toe of the landslide site (Fig. 5a). Due to the intersection of these joints, a blocky appearance was observed with the block size varying between 4 to $20 \mathrm{~cm}$. In the crown area, 
four sets of joints were observed (Fig. 5b) and the rocks therein had crumbled and had a comparatively smaller block size than the toe. The dip and dip direction of the joints is reported in Table 1 . The joint friction angle was $41^{\circ}$. The analysis indicates that there is no possibility of structurally controlled failure at the toe of the landslide but toppling failure is likely to occur at the crown (Fig. 6).

Table 1 Summary of joint sets observed at toe and crown of the landslide site

\begin{tabular}{|c|c|c|c|c|c|c|c|}
\hline Site & Joint set number & Dip direction & Dip & Site & Joint set number & Dip direction & Dip \\
\hline \multirow{4}{*}{ Toe } & $\mathrm{J} 1$ & $\mathrm{~N} 50^{\circ}$ & $40^{\circ}$ & \multirow[t]{4}{*}{ Crown } & $\mathrm{J} 1$ & $\mathrm{~N} 90^{\circ}$ & $85^{\circ}$ \\
\hline & $\mathrm{J} 2$ & $\mathrm{~N} 20^{\circ}$ & $85^{\circ}$ & & $\mathrm{J} 2$ & $\mathrm{~N} 20^{\circ}$ & $80^{\circ}$ \\
\hline & J3 & $\mathrm{N} 290$ & $80^{\circ}$ & & $\mathrm{J} 3$ & $\mathrm{~N} 250^{\circ}$ & $80^{\circ}$ \\
\hline & Slope Face & $\mathrm{N} 220^{\circ}$ & $65^{\circ}$ & & Slope Face & $\mathrm{N} 220^{\circ}$ & $60^{\circ}$ \\
\hline
\end{tabular}

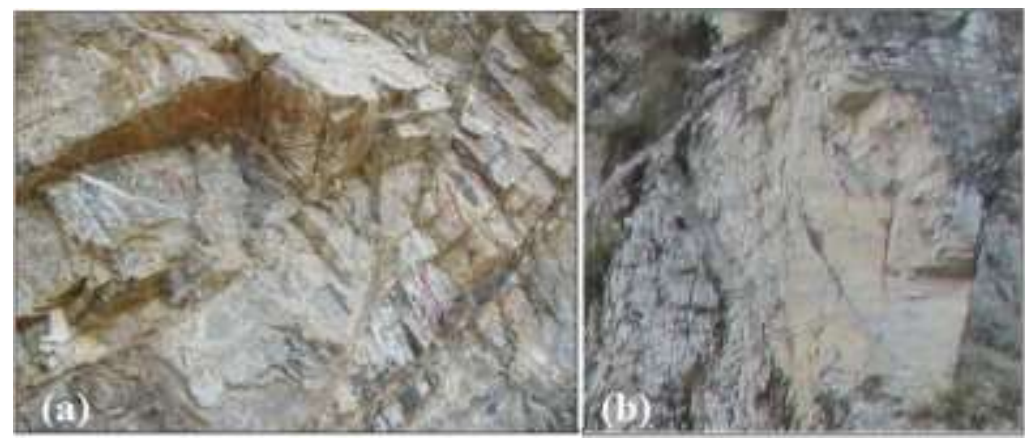

Fig. 5 View of blocky formation due to the intersection of joint sets landslide toe (a) and crown (b)

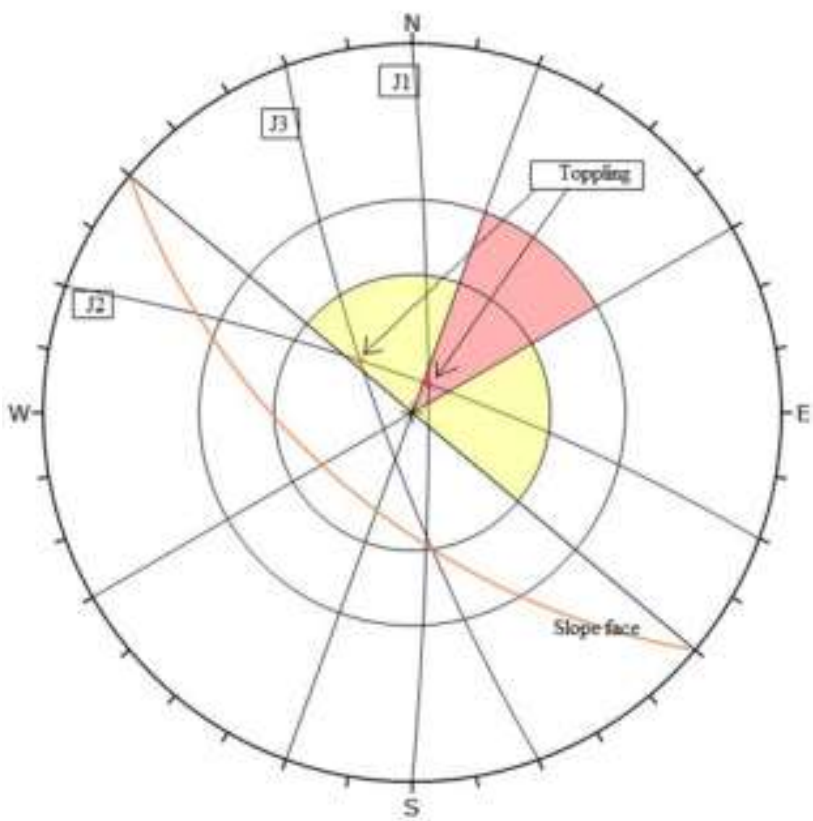

Fig. 6 Kinematic analysis of jointed rock mass for toppling failure at the crown location

\subsection{Ground Penetration Radar Investigations}

GPR survey was conducted to explore the subsurface geology and mass movement. The working principle of the GPR is to generate a short pulse of high-frequency electromagnetic wave that is transmitted by the transmitting antenna through the ground surface. Reflections from boundaries between layers are received by the receiving antenna. The amount of the reflected wave's energy depends upon the difference in the relative dielectric permittivity (Er) between the two layers. When this is high, the energy reflected shows a clear contrast. The depth of penetration by the electromagnetic waves is highly site-specific and is restricted by attenuation of the outgoing 
pulse. In general, greater penetration is obtained in dry, sandy and rocky soils and less penetration is obtained for moist, clayey and conductive soils (Wolf et al. 1998; Batayneh et al. 2002).

The GPR device used in the present study was developed by the Norwegian Geotechnical Institute and works on the step-frequency principle in the frequency range of $2 \mathrm{MHz}$ to $6 \mathrm{GHz}$ with an antenna having $100 \mathrm{MHz}$ central frequency, which can penetrate the ground by up to $15 \mathrm{~m}$. GPR survey lines were placed on a service road of the national highway. GPR Survey Line-1 is just above the scarp area, the total run of profile length was around $280 \mathrm{~m}$ and the depth of penetration was $15 \mathrm{~m}$. From the reflection profile of the survey, Line-1 shows no evidence of bedrock up to a depth of $15 \mathrm{~m}$. The processed reflection profile in Fig. 7 clearly indicates sagging of the soil layers in the sinking zone below the Surbhi Resort. Similarly, a soil mass is indicated in the subsiding layers. In the case of survey lines-2 and 3, strong reflections revealed existence of rock strata.

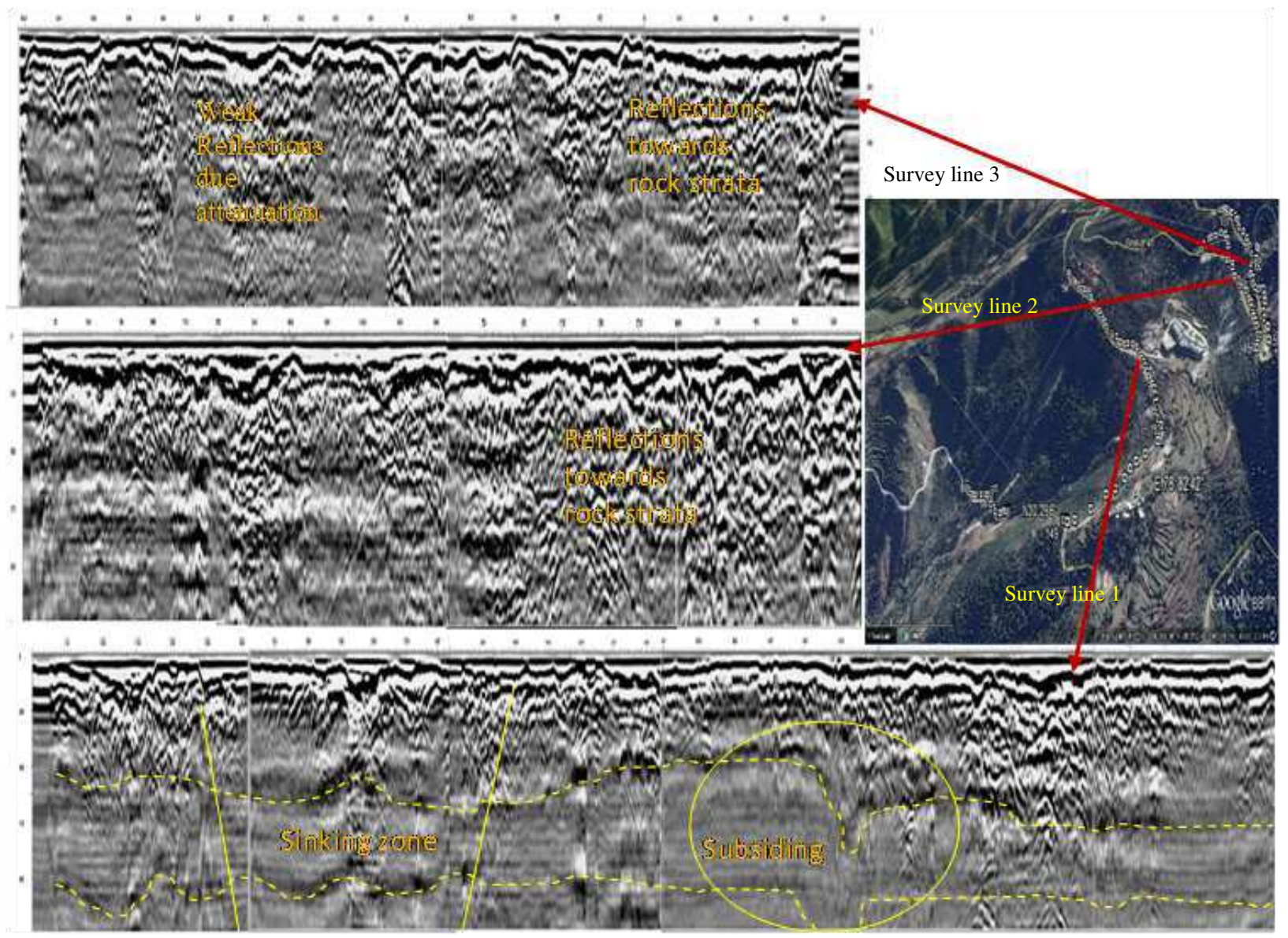

Fig. 7 GPR reflection profiles showing cross-sectional profiles of subsurface strata

\subsection{Geotechnical Characterization of Geomaterials}

A slope failure is triggered when the shear stress acting along the potential failure surface exceeds the shear strength of the soil or rock. Soil and rock samples were collected from the landslide site. Characterisation of the soil samples was performed. Grain size distribution was analysed to classify the soil mass. Direct shear testing was performed on remoulded soil samples of different sizes to measure the internal friction angle $(\phi)$. The XRD analysis was conducted to identify the minerals in the debris material. Point-load strength-index test was performed on irregular 
rock chunks to estimate the compressive strength. For jointed rock mass, non-linear strength criteria were used to measure the shear strength parameters.

\subsection{Laboratory Tests}

\subsubsection{Shear tests on soil samples}

Characterisation of the soil forming the slope is the first step in estimating the shear strength parameters of the soil mass. Soil samples were collected from the the landslide site. Sieve analysis was conducted on samples of 1 and 50 $\mathrm{kg}$ to examine the effect of gravel content on grain size distribution (GSD). Fig. 8 shows GSD curves for the two cases. As per the IS: 2720 Part 4 (1985), the soil types were classified as SW-SC and GW for the samples weighing 1 and $50 \mathrm{~kg}$, respectively. The percentages of gravel in the samples were $33.8 \%$ and $58.72 \%$, respectively. As the gravel fraction increased substantially with sample size, it was decided to conduct conventional triaxial tests and large size direct shear tests $\left(30 \times 30 \times 20 \mathrm{~cm}^{3}\right)$.

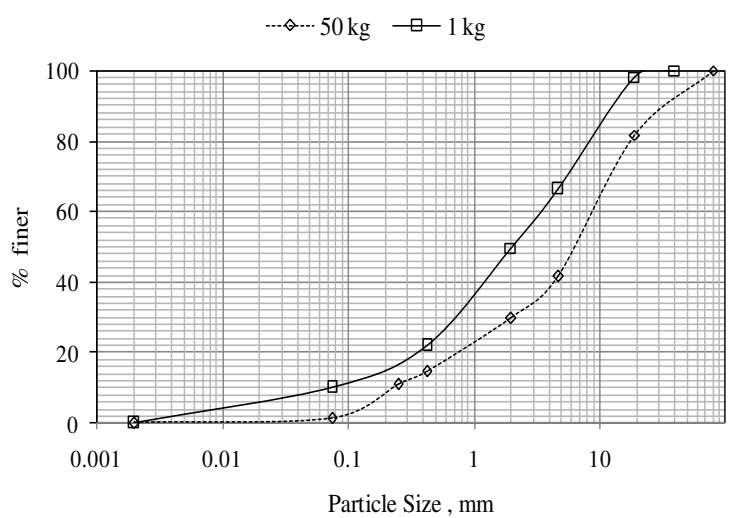

Fig. 8 Grain size distribution for samples of $1 \mathrm{~kg}$ and $50 \mathrm{~kg}$

Debris material that could pass through a $4.75 \mathrm{~mm}$ sieve (i.e., the sand-fines matrix) was used for the conventional triaxial tests. The conventional size of the specimen is about $38 \mathrm{~mm}$ diameter and $76 \mathrm{~mm}$ height. The soil was mixed at natural moisture and specimen was remoulded at unit weight of $19 \mathrm{kN} / \mathrm{m}^{3}$ by compacting in layers. Consolidated undrained triaxial tests were perfomed at a constant loading rate of $1.25 \mathrm{~mm} / \mathrm{min}$ until failure. Four specimens were tested at confining pressures $\left(\sigma_{3}\right)$ of $100,150,200$ and $300 \mathrm{kPa}$. Test results were used to determine the possible value of cohesion and friction angle of sand fines matrix. Fig. 9 shows the results of triaxial testing presented as

major principal stress $\left(\sigma_{1}\right)$ vs. axial strain and p $\left(\frac{\sigma_{1}+\sigma_{3}}{2}\right)$ vs. q $\left(\frac{\sigma_{1}-\sigma_{3}}{2}\right)$ plots. Shear-strength parameters $c$ and $\phi$ obtained for the sand-fines matrix from conventional triaxial tests were found to be $41.98 \mathrm{kPa}$ and $33.7^{\circ}$, respectively. As the tests were perfomed on remoulded samples, it is more likely that the cohesion and friction angle of debris material are expected to be higher in the field as compated to esperimental. 

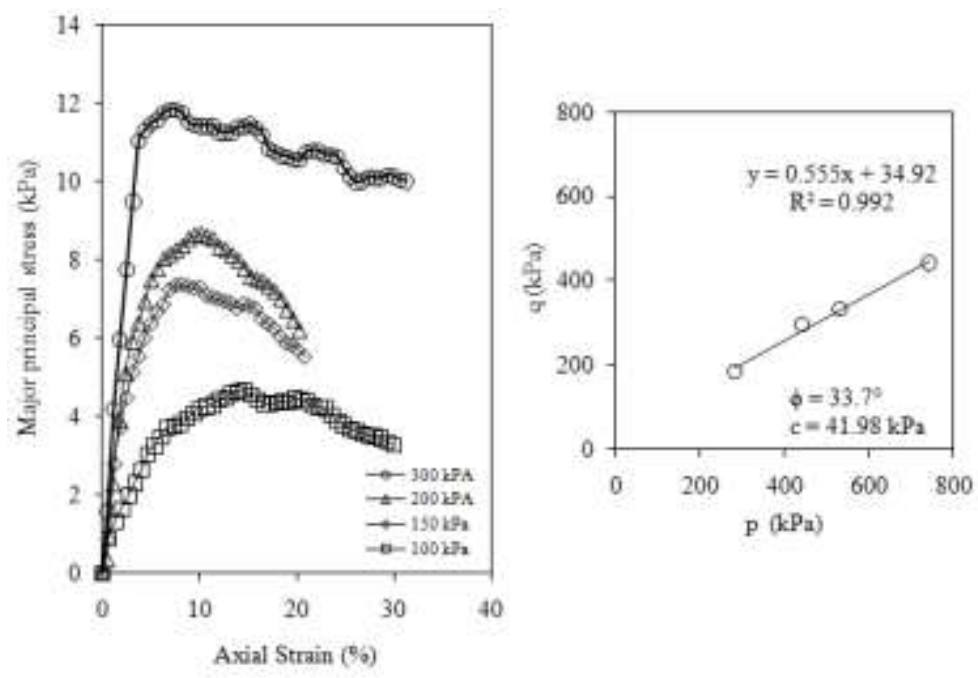

Fig. 9 Results of small size direct shear tests

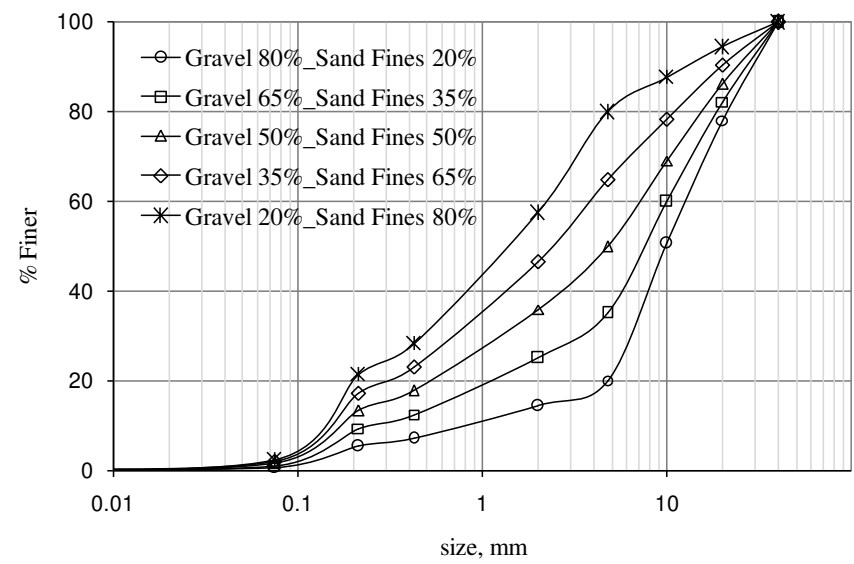

Fig. 10 Grain size distribution plots for specimens with different gravel content

Irfan and Tang (1993) has attempted, through extensive literature review followed by large size shear tests, to investigate the increase in shear strength with addition of coarser fraction to sand fines matrix. The authors stated that the friction angle of soil mass with coarser rock particles increases linearly with increasing proportion of coarser particles, while cohesion changes negligibly. Li (2013) stated that the relative proportion of sand fines matrix and coarse fractions of composite soil significantly influences the shear-strength parameters, especially friction angle. Hence large-sized direct shear tests were planned on remoulded samples at different gradations (Fig. 10) by varying the gravel content. The main objective of performing direct shear testing with varying gravel fractions was to obtain more insight into the response of friction angle $(\phi)$ with respect to the change in gradation of the gravel since the gravel content in the field is varying in the range of 30 to $60 \%$. Large size direct shear test samples were prepared at different gradations by mixing gravel content from 20 to $80 \%$ to the sand fines matrix. The materials in size range of $4.75 \mathrm{~mm}$ to $40 \mathrm{~mm}$ were used as gravel content for large size specimens. Specimens were prepared at similar unit weight of $19 \mathrm{kN} / \mathrm{m}^{3}$ and moisture content in the samples was maintained around $5 \%$. The specimens were prepared in three layers by compacting each layer with a $2.4 \mathrm{~kg}$ steel rammer. The tests were carried out at normal stress levels varying from 5 to $150 \mathrm{kPa}$. The results are presented in the form of shear stress vs. shear displacement plots and failure envelopes in Fig. 11, indicating that as the gravel content increased, $\phi$ also increased. These details are elaborated in the next section. 

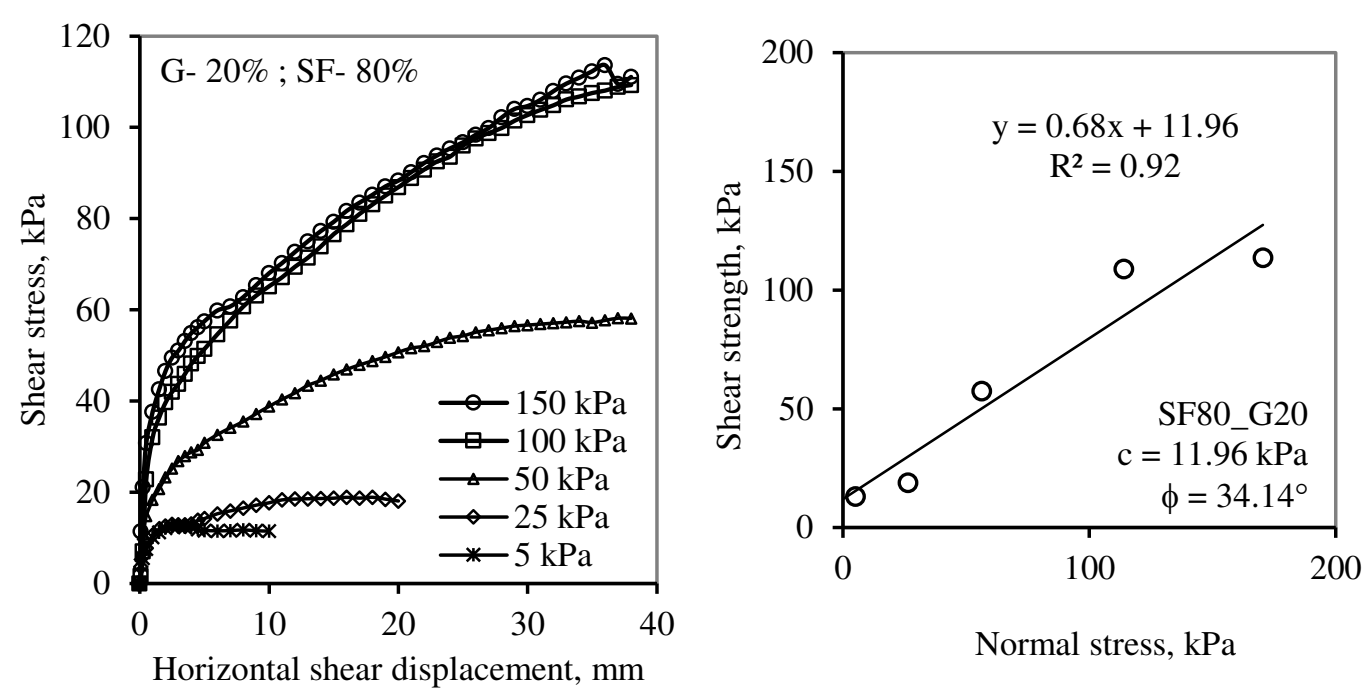

Normal stress, kPa
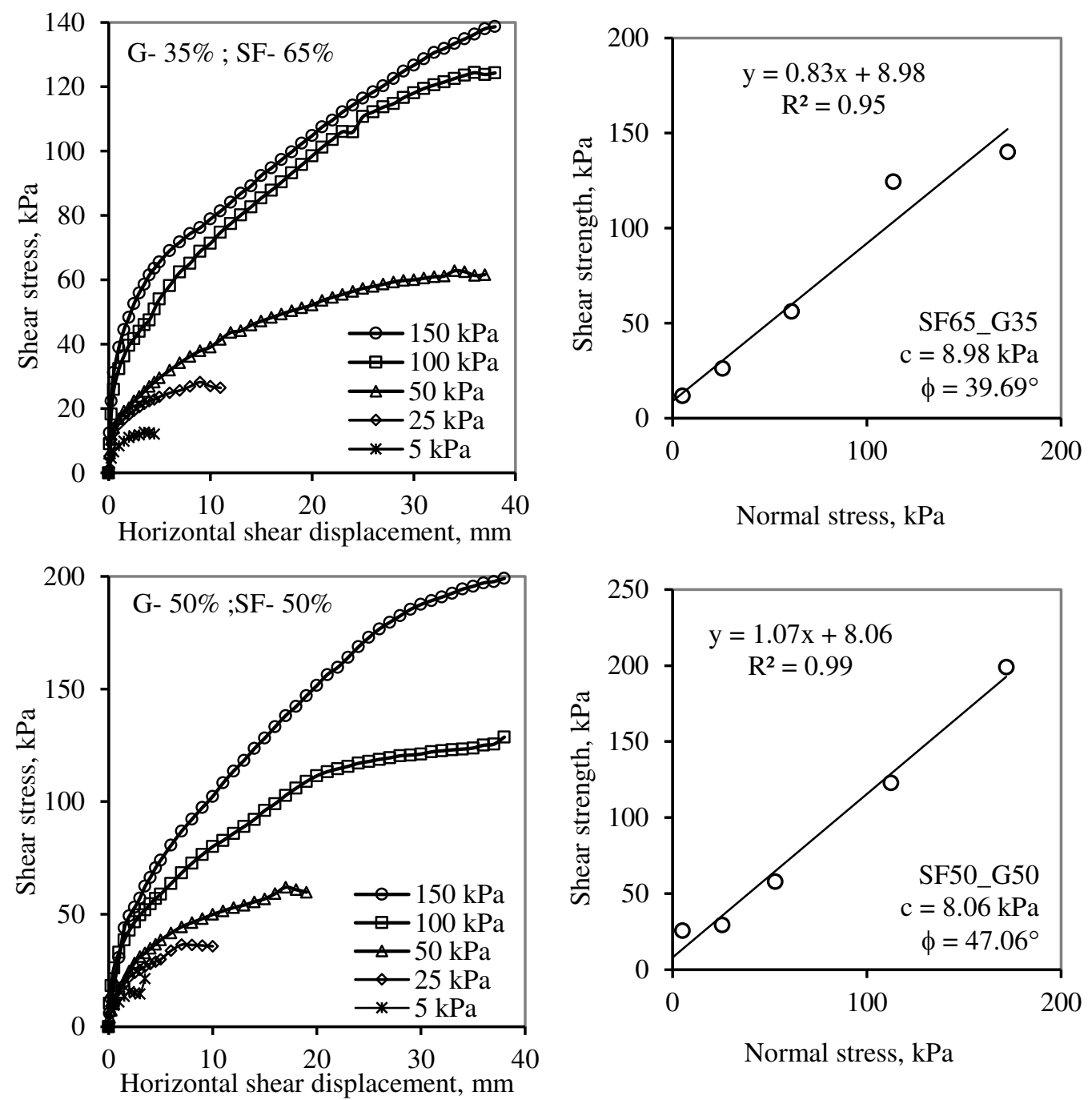

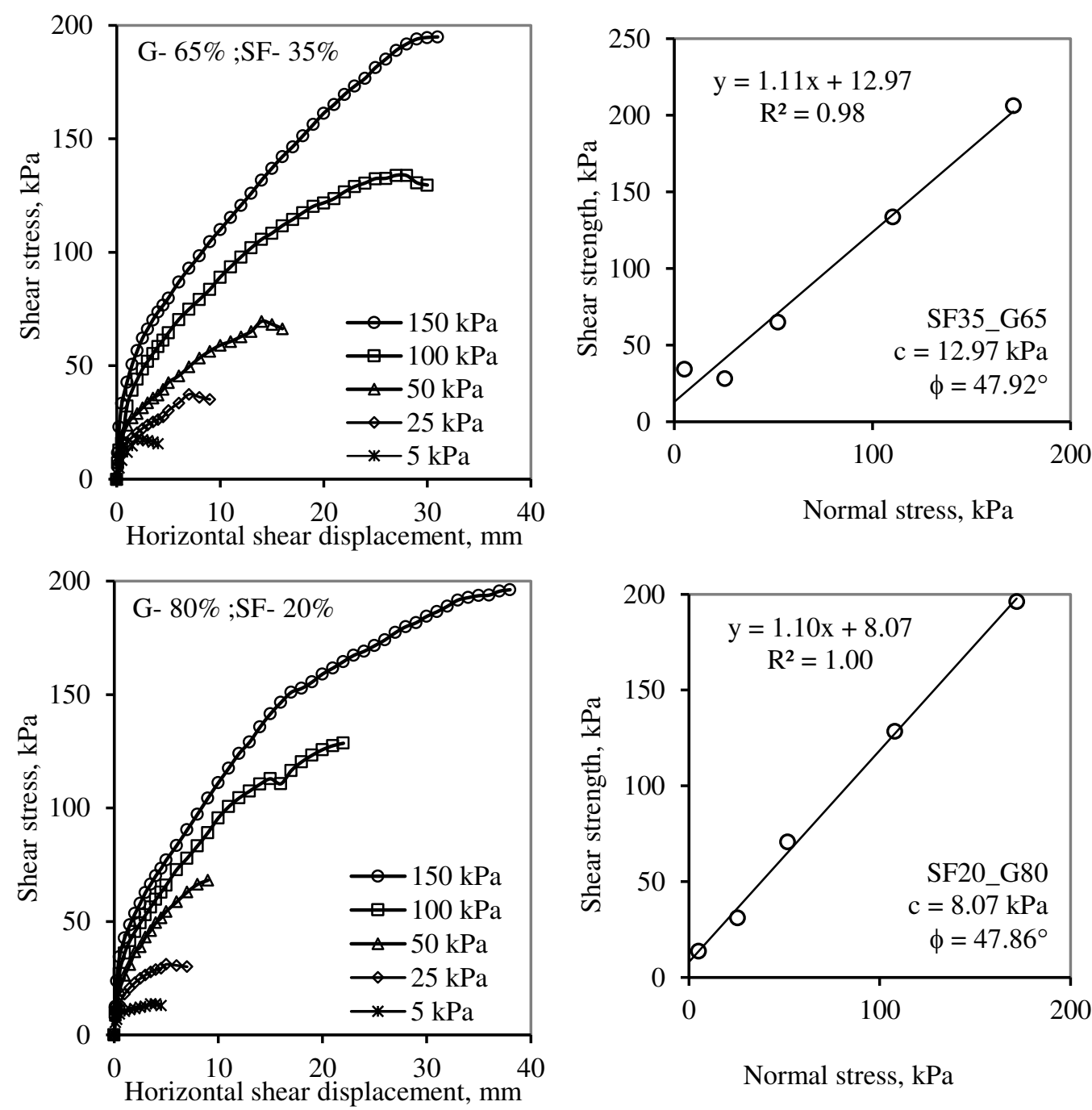

Normal stress, $\mathrm{kPa}$

Fig. 11 Results of large size direct shear tests with different proportion of gravels (G) and sand fines (SF)

Ideally, undisturbed samples extracted from the field should be tested, but owing to the large variation in soil mass composition, it is not feasible to do tests for all compositions. Although good insight into the variation in $\phi$ was obtained, cohesion measured by direct shear testing is not the same as in the field value as tests were perfomed on remoulded samples with moisture content of 5\% and cohesion is lost during remoulding. Nevertheless, a representative cohesion value for the overall slope can be obtained through back-analysis. The mineral composition has a significant role in the shear-strength behaviour of a soil sample and gives a good indication of cohesion in the field. Thus, XRD analysis was performed on the sand-fines matrix to explore the predominant minerals in the slopeforming materials (Fig. 12). The results reveal that debris material predominantly comprises of calcium carbonate $\left(\mathrm{CaCO}_{3}\right)$ and clay. The approximate proportions of calcareous elements oxygen $(\mathrm{O})$, calcium $(\mathrm{Ca})$ and carbon $(\mathrm{C})$ were 47\%, 15.5\%, and 13.2\%, respectively. Clay elements silica (Si), magnesium (Mg), aluminium (Al) and potassium $(K)$ were $12.0 \%, 2.6 \%, 1.4 \%$ and $2.3 \%$, respectively. Based on the elemental composition, the debris material was designated as a gravelly calcareous-type deposits. The presence of $\mathrm{CaCO}_{3}$ indicates the likelihood of relatively high cohesion in the field. Triaxial test results of sand fines matrix exhibited relatively higher cohesion value $(\mathrm{c}=41.98 \mathrm{kPa}$ ) although tests were perfomed on remoulded specimens. 


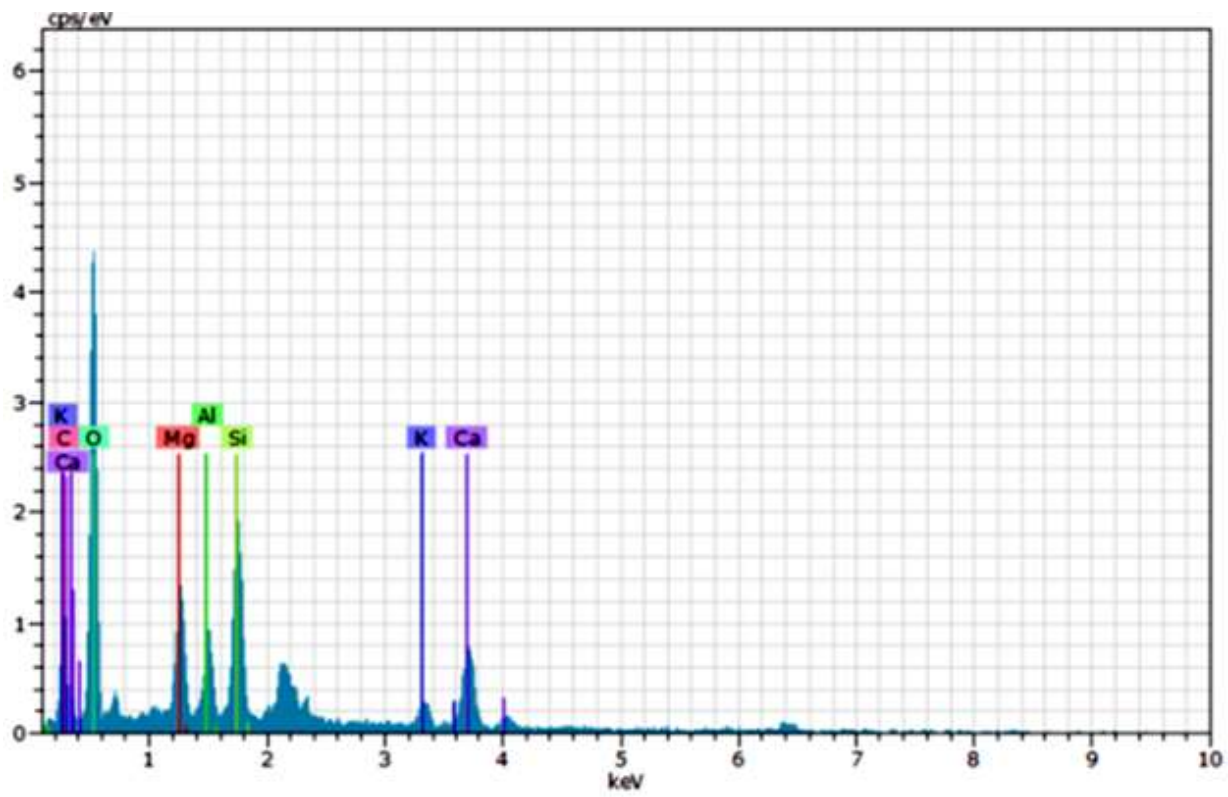

Fig. 12 XRD patterns for sand fines of debris material

\subsubsection{Effect of gravel content on the angle of internal friction, $\phi$}

In the field, gravel content substantially varies over a wide range, which in turn markedly influences the friction angle, $\phi$. Dupla et al. (2007) performed triaxial tests on soil-rock mixtures and concluded that the volumetric fraction of gravel is the main cause that affects the shear-strength parameters and elastic properties. Studies have been conducted in the past to establish a correlation between $\phi$ and gravel content (Irfan and Tang 1993; Lindquist 1994; Modley 1999; Iannacchione and Vallejo 2000; Xu et al. 2011; Wang et al. 2017;Wang et al. 2020). This is helpful for obtaining the field value of $\phi$ based on the gravel content at a particular location.

In the present laboratory investigation, the gravel fraction was varied from $20 \%$ to $80 \%$ in order to study the increase in friction angle compared to that of sand fines matrix $\left(\phi_{\mathrm{sf}}=33.7^{\circ}\right)$. The increase in friction angle obtained by varying the gravel content was plotted against the percentage of gravel content (Fig. 13). The results reveal that when the gravel content was less than 20\%, there was a negligible increase of $2^{\circ}$ to $3^{\circ}$ in the friction angle with an increase in gravel content. When the fraction of gravel content was in the range of $20 \%$ to $65 \%$, the friction angle increased by $4.2^{\circ}$ for every $10 \%$ increase in gravel content. When the gravel content was above $65 \%$, $\phi$ did not change significantly. Indeed, Irfan and Tang (1993) and Lindquist (1994) observed similar behaviour: a linear increase in friction angle for gravel content of $25 \%$ to $75 \%$ and almost constant above $75 \%$. Moreover, Medley (1999) found a linear increase with an increase in gravel content from $15 \%$ to $40 \%$. 


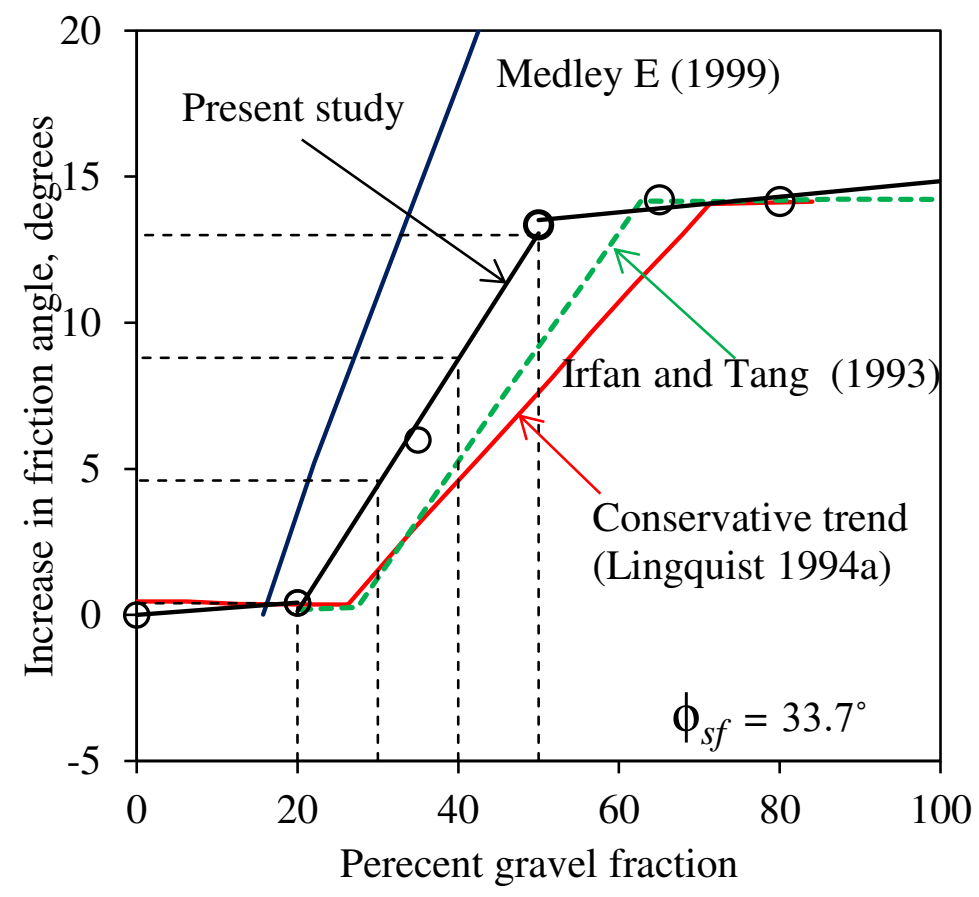

Fig. 13 Increase in the angle of internal friction with percent gravel content (after Medley, 1999)

\subsubsection{Rock samples}

The rock type encountered in the study region comprised of intraclasts of fractured dolomitic limestone that were highly jointed in nature, and it was very difficult to obtain the required size of intact cores for testing. Thus, irregular rock chunks were collected from the field. Point-load strength-index test was performed to estimate the compressive strength of the intact rock. The strength of rock mass was calculated using empirical correlations based on various classification systems, as listed in Table 2. Assessment of rock quality designation (RQD), RMR, Q and GSI results were made based on field observations. Triaxial strength values for jointed rocks were simulated using non-linear failure criteria.

\subsubsection{Simulation of triaxial strength of rock mass}

\section{a. Strength criteria}

A strength criterion expresses the strength behaviour of the rock as a function of confining pressure. The conventional linear Mohr-Coulomb criterion is the most widely used for geomaterials. However, jointed rocks exhibit highly non-linear strength behaviour, especially under low-stress levels. Thus, two non-linear strength criteria were used to simulate the strength behaviour of rock mass while assuming the equivalent parameters of the linear Mohr-Coulomb criterion:

a. The Generalised Hoek and Brown (GHB) Criterion (Hoek et al. 2002): The criterion was proposed for assessing the strength behaviour of isotropic intact and heavily jointed isotropic rock masses. The criterion, in general form, is expressed as:

$$
\sigma_{1}=\sigma_{3}+\sigma_{c i}\left(m_{b} \frac{\sigma_{3}}{\sigma_{c i}}+s\right)^{a}
$$


where $\sigma_{1}$ and $\sigma_{3}$ are the major and minor principal stresses at failure; $\sigma_{\mathrm{ci}}$ is the unconfined compressive strength of the intact rock; $\mathrm{m}_{\mathrm{b}}$, $\mathrm{a}$, and $\mathrm{s}$ are the criterion parameters and are obtained using empirical correlations (Hoek and Brown 2018).

b. The Modified Mohr-Coulomb (MMC) Criterion(Singh and Singh 2012): The criterion can be used to describe the behaviour of rock mass under triaxial stress condition. The uniaxial compressive strength (UCS) of the rock mass is an input parameter to this criterion. The UCS of the rockmass, $\sigma_{\text {cmass }}$ is assessed through classification systems. The MMC strength criterion incorporates the critical state concept for rock (Barton, 1976). The criterion is expressed as:

$\sigma_{1}-\sigma_{3}=\sigma_{\mathrm{cmass}}+\frac{2 \sin \phi_{\mathrm{j} 0}}{1-\sin \emptyset_{\mathrm{j} 0}} \sigma_{3}-\frac{1}{\sigma_{\mathrm{ci}}} \frac{\sin \phi_{\mathrm{j} 0}}{\left(1-\sin \phi_{\mathrm{j} 0}\right)} \sigma_{3}{ }^{2} \quad$ (for $0 \leq \sigma_{3} \leq \sigma_{\mathrm{ci}}$ )

Where $\phi_{\mathrm{j} 0}=\frac{(1-\mathrm{SRF})+\frac{\sin \phi_{\mathrm{i} 0}}{1-\sin \phi_{\mathrm{i}}}}{(2-\mathrm{SRF})+\frac{\sin \phi_{\mathrm{i}}}{1-\sin \phi_{\mathrm{i} 0}}}$

where $\phi_{\mathrm{i} 0}$ is the angle of internal friction of intact rock corresponding to very small confining pressure $\left(\sigma_{3} \rightarrow 0\right)$. SRF is a strength reduction factor, expressed as:

$$
S R F=\frac{\sigma_{c m a s s}}{\sigma_{c i}}
$$

Where $\sigma_{c i}$ is the UCS of intact rock. The criterion is applicable for anisotropic rock mass as well as isotropic rock mass.

To obtain $\phi_{\mathrm{i} 0}$, UCS and triaxial strength tests on the intact rock will be required. If triaxial strength tests on the intact rock are not feasible, a rough estimate of the triaxial strength of the intact rock may be made as suggested by Singh and Singh (2005):

$$
\begin{aligned}
& \left(\sigma_{1}-\sigma_{3}\right)=\mathrm{A}_{\mathrm{i}}-2 \mathrm{~A}_{\mathrm{i}} \sigma_{c i} \sigma_{3}+\sigma_{c i} ; 0 \leq \sigma_{3} \leq \sigma_{\mathrm{ci}} \\
& \text { Where } A_{i} \cong-3.97\left(\sigma_{\mathrm{ci}}\right)^{-1.10} ; B_{i}=-2 \mathrm{~A}_{\mathrm{i}} \sigma_{c i} ; \sin \phi_{i 0}=\frac{B_{i}}{2+B_{i}}
\end{aligned}
$$

Point-load strength-index testing was conducted on 55 irregular lumps; the calculated strength values were in the range of 10 to $115 \mathrm{MPa}$, exhibiting wide scatter of the data. Statistical tools were used to extract representative values from the scattered data, while a Weibull distribution was used to model the strength behaviour of the rocks. Fig. 14 shows the fitted Weibull distribution to the strength data, with the plot showing the cumulative distribution function of the obtained strength values. The y-coordinate for a point on the curve indicates the probability of the strength as less than or equal to the x-coordinate of the point. A value of strength equal to 60 MPa corresponding to a $50 \%$ probability was considered to be representative.

Rock mass classification systems RQD (Deere 1963), RMR (Barton et al. 1974), Q (Barton et al. 1974) and GSI (Hoek 1994) were used to assess rock mass strength $\left(\sigma_{\text {cmass }}\right)$. Based on field observations, the RMR, $Q$ and GSI values were estimated as 53, 2.56 and 65, respectively. The values of $\sigma_{\text {cmass }}$ obtained from several well-known correlations are given in Table 2 , with the computed $\sigma_{\text {cmass }}$ values varying over a wide range. The Weibull probability distribution plot for the computed $\sigma_{\text {cmass }}$ values is shown in Fig. 15, from which a representative value of $\sigma_{\text {cmass }}$ is considered to be 10.0 MPa. 


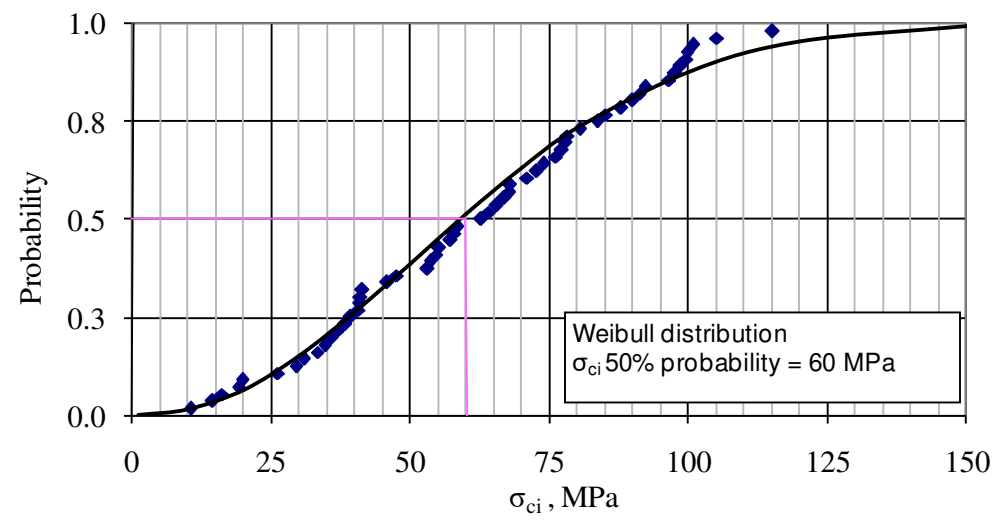

Fig. 14 Weibull's distribution plot for compressive strength $\left(\sigma_{\mathrm{ci}}\right)$ of rock

Table 2 Empirical equations for calculation of uniaxial compressive strength for rockmass

\begin{tabular}{|c|c|c|c|c|}
\hline S.No & $\begin{array}{l}\text { Eq. } \\
\text { No }\end{array}$ & Reference & Equation & $\sigma_{\text {cmass }}(\mathrm{MPa})$ \\
\hline 1 & 7 & Hoek and Brown (1980) & $\frac{\sigma_{\text {cmass }}}{\sigma_{c i}}=\sqrt{s} ;\left(s=e^{(R M R-100) / 9}\right)$ & 4.41 \\
\hline 2 & 8 & Yudhbir and Prinzi (1983) & $\frac{\sigma_{\text {cmass }}}{\sigma_{c i}}=e^{\frac{7.65 *(R M R-100)}{100}}$ & 1.65 \\
\hline 3 & 9 & $\begin{array}{l}\text { Ramamurthy et al. (1985) } \\
\text { and Ramamurthy (1986) }\end{array}$ & $\frac{\sigma_{\text {cmass }}}{\sigma_{c i}}=e^{\frac{(R M R-100)}{18.75}}$ & 4.89 \\
\hline 4 & 10 & $\begin{array}{l}\text { Trueman (1988) and Asef } \\
\text { et } \mathrm{al}(2000)\end{array}$ & $\frac{\sigma_{c m a s s}}{\sigma_{c i}}=0.5 * e^{0.06 * R M R}$ & 12.02 \\
\hline 5 & 11 & $\begin{array}{l}\text { Kalamaras and Bieniawski } \\
(1995)\end{array}$ & $\frac{\sigma_{c m a s s}}{\sigma_{c i}}=e^{\frac{(R M R-100)}{24}}$ & 8.47 \\
\hline 6 & 12 & Sheorey et al. (1989) & $\frac{\sigma_{\text {cmass }}}{\sigma_{c i}}=e^{\frac{(R M R-100)}{20}}$ & 5.72 \\
\hline 7 & 13 & Aydan et al. (1997) & $\sigma_{\text {cmass }}=0.0016 R M R^{2.5}$ & 32.72 \\
\hline 8 & 14 & Aydan and Dalgic (1998) & $\frac{\sigma_{\text {cmass }}}{\sigma_{c i}}=\frac{R M R}{R M R+6 *(100-R M R)}$ & 9.49 \\
\hline 9 & 15 & Zhang (2010) & $\frac{\sigma_{c m a s s}}{\sigma_{c i}}=10^{0.013 * R Q D-1.34}$ & 5.63 \\
\hline 10 & 16 & Singh and Goel (1999) & $\begin{array}{l}\sigma_{\text {cmass }}=7 * \gamma * f_{c} * Q^{\frac{1}{3}} \\
\text { Where } f_{c}=\frac{\sigma_{c}}{100}, \text { for } \mathrm{Q}>10 \text { and } \sigma_{\mathrm{ci}}>100, \text { otherwise } f_{c}= \\
1 ; \gamma \text { is the unit weight of rock mass, } \mathrm{g} / \mathrm{cm}^{3}\end{array}$ & 24.91 \\
\hline 11 & 17 & Singh et al. (1997) & $\begin{array}{l}\qquad \sigma_{\text {cmass }}=7 * \gamma * Q^{\frac{1}{3}} \\
\text { for } \mathrm{Q}<10,2<\sigma_{c}<100 \mathrm{MPa}, \mathrm{SRF}=2.5 \\
\gamma \text { is the unit weight of rockmass, } \mathrm{g} / \mathrm{cm}^{3}\end{array}$ & 24.91 \\
\hline 12 & 18 & Barton (2002) & $\begin{array}{l}\sigma_{\text {cmass }}=5 * \gamma *\left(\frac{Q * \sigma_{c}}{100}\right)^{1 / 3} \\
\gamma \text { is the unit weight of rock mass, } \mathrm{g} / \mathrm{cm}^{3}\end{array}$ & 15.01 \\
\hline \multicolumn{4}{|c|}{ As per the Weibull distribution at $50 \%$ probability $\sigma_{\mathrm{cmass}}$} & 10.0 \\
\hline
\end{tabular}




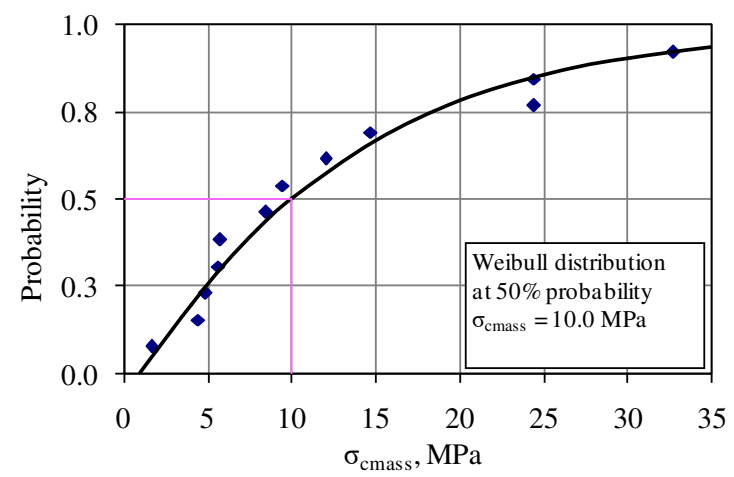

Fig. 15 Weibull's distribution plot for $\sigma_{\text {cmass }}$

\section{b. Shear Strength parameters of rock mass}

Triaxial strength values for the rock mass were simulated using the GHB and MMC failure criteria. GSI $=65$ was used for GHB, while $\sigma_{\text {cmass }} 10.0 \mathrm{MPa}$ was required as an input parameter for MMC. Triaxial strength values $\sigma_{1}$ for different $\sigma_{3}$ were obtained for both the criteria. Fig. 16 shows the failure envelopes for the GHB and MMC criteria. Cohesion $\mathrm{c}_{\text {mass }}$ and friction angle $\phi_{\text {mass }}$ for the rock mass were obtained with GHB and MMC by fitting the strength value data with the linear Mohr-Coulomb shear-strength parameters (Table 3). It can be observed that the same cohesion values were obtained with both criteria whereas a slightly higher friction angle was obtained with MMC. Hence, the predicted results were similar despite using independent parameters in both criteria.

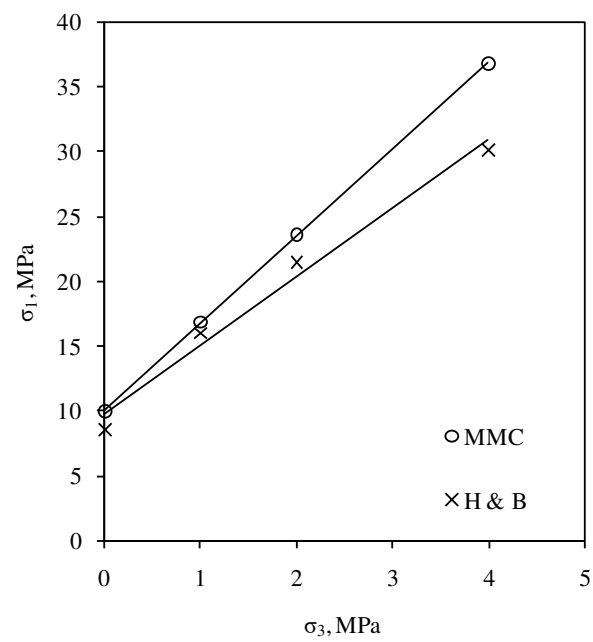

Fig. 16 Failure envelopes for rockmass

Table 3 Summary of equivalent Mohr-Coulomb shear strength parameters for rock mass

\begin{tabular}{|l|c|c|}
\hline \multicolumn{1}{|c|}{ Particulars } & $\mathrm{c}_{\text {mass }}(\mathrm{MPa})$ & $\phi_{\text {mass }}(\mathrm{deg})$. \\
\hline Generalized Hoek \& Brown Criterion & 2.07 & $43.3^{\circ}$ \\
\hline Modified Mohr Coulomb criterion & 1.95 & $47.7^{\circ}$ \\
\hline
\end{tabular}

\subsection{Stability analysis of the slope}

Stability analysis was carried out by using the software Slide (Rocscience, Inc. 2005). The profile of the landslide site in Fig. 4 was used for the stability analysis, in which delineation of the debris layer was drawn based on the GPR reflection profiles and field investigations. A summary of the Mohr-Coulomb shear strength parameters of the 
soil with varying gravel content is given in Table 4. The slope was assumed to be dry in the preliminary analysis. Stability analysis of the slope section was carried out for six compositions of debris material, starting from the sandfines matrix and then increasing the gravel content from $20 \%$ to $80 \%$ (Table 4). The results are presented as factor of safety (FOS) values (Table 4). For c values from 8.06 to $41.98 \mathrm{kPa}$ and $\phi$ values from $33.7^{\circ}$ to $48^{\circ}$, the FOS was observed to be in the range of 0.47 to 0.70 and the slope was found to be unstable even under dry conditions. Since the slope had not failed in the field, the FOS should have been equal to or greater than 1. As the laboratory tests were not performed on undisturbed samples, it is envisaged that actual cohesion in the field might be higher than that obtained in the laboratory tests. In agreement with this, Wan and Kwong (2002) mentioned that of the shear strength parameters, interlocking cohesion is likely to be underestimated when tests are performed on disturbed samples. The possibility of higher cohesion was also evident from the fact that in the field, slopes almost 4 to $5 \mathrm{~m}$ high were found to be stable even after rainfall. Furthermore, the calcareous content is substantial, which indicates the possibility of high cohesion. Potro and Hurlimann (2008) advocated that shear strength parameters should be adjusted/back-calculated according to the field characteristics. Therefore, a parametric analysis was performed in the present study to back-calculate the cohesion of the debris material.

Table 4 Summary of slope stability analysis results

\begin{tabular}{|c|c|c|c|c|}
\hline Test type & Slope Model & $\mathrm{c}, \mathrm{kPa}$ & $\phi\left(^{\circ}\right)$ & $\mathrm{FOS}$ \\
\hline Triaxial & Sand fines matrix & 41.98 & 33.7 & 0.76 \\
\hline \multirow{3}{*}{ Direct shear } & $20 \%$ gravel + 80\% sand fines & 11.92 & 33.6 & 0.47 \\
\cline { 2 - 5 } & $35 \%$ gravel + 65\% sand fines & 12.67 & 39.2 & 0.55 \\
\cline { 2 - 5 } & $50 \%$ gravel + 50\% sand fines & 9.1 & 46.23 & 0.61 \\
\cline { 2 - 5 } & $65 \%$ gravel + 35\% sand fines & 11.1 & 47.83 & 0.67 \\
\cline { 2 - 5 } & $80 \%$ gravel + 20\% sand fines & 13.05 & 48.2 & 0.70 \\
\hline
\end{tabular}

In the parametric analyses, the slope mass is usually considered as dry, occasionally as fully saturated and rarely as fully saturated with seismic loading. Among these, the partially or fully saturated state is considered to be the worst likely condition quite often encountered in the field after heavy rainfall. The effect of saturation may be considered in many ways. A convenient way is to use pore water pressure coefficient $R_{u}$, which is 0 for a dry slope. Higher values of $\mathrm{R}_{\mathrm{u}}$ indicate a higher degree of saturation. In the field, the degree of saturation of the slope mass depends on the intensity of rainfall and soil characteristics that govern the infiltration of water into the soil mass. It is very difficult to assess $R_{u}$ in the field for the worst-case scenario, so it was decided to use values of 0, 0.05, 0.1 and 0.15. Moreover, the $\phi$ values varied from $40^{\circ}$ to $48^{\circ}$ (the laboratory tests indicated $\phi$ varying from $39^{\circ}$ to $48^{\circ}$ ) when gravel content was varied from $35 \%$ to $65 \%$, and different values of cohesion (c) were used. FOS values were obtained for various combinations of $\phi$ and $\mathrm{c}$ values.

From the results of the parametric analysis, slope profiles with critical slide surfaces were obtained for $\mathrm{c}=50 \mathrm{kPa}$ and $\mathrm{R}_{\mathrm{u}}=0.10$ with $\phi$ values from $40^{\circ}$ to $48^{\circ}$ (Fig.17). When $\mathrm{c}=50 \mathrm{kPa}$ and $\phi=40^{\circ}$, the slope was unstable with FOS $=0.77$. As $\phi$ varied between $40^{\circ}$ to $48^{\circ}$, the FOS increased, although it was still less than 1 . Fig. 18 shows the variation of FOS with cohesion for different $\phi$ values when the slope is in a dry to partially saturated state. The results indicate that $R_{u}$ has a significant effect on FOS. When $R_{u}=0$, the FOS values were greater than 1 for $c$ in the range of $50-100 \mathrm{kPa}$, indicating that the slope is in a stable state under dry conditions. Moreover, FOS was lowered drastically as $R_{u}$ increased from 0.05 to 0.15 . Although there was a high intensity of rainfall reported in the study area, $R_{u}=0.15$ was considered to be too high for the material type observed at the site, thus the value of $R_{u}$ is likely 
to vary between 0 and 0.1 in the field when the slope is under to dry to saturated state, respectively. The backanalysis was perfomed to obtain the possible range of cohesion likely to exist in the field.

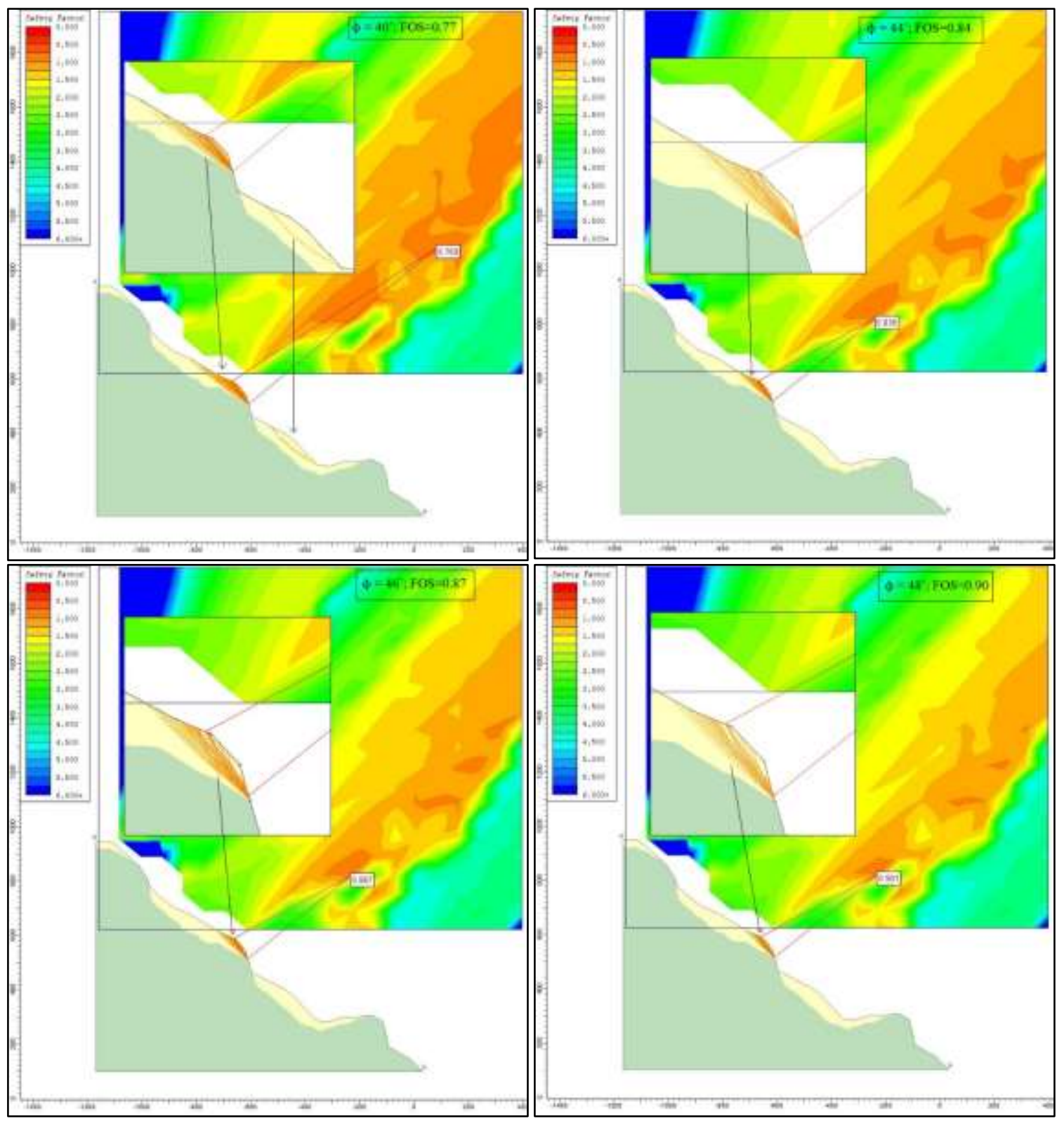

Fig. 17 Possible slip surfaces for a case of $\mathrm{c}=50 \mathrm{kPa}$

At the slope site, the gravel content in the debris was found to vary from $30 \%$ to $60 \%$. Thus, the slope model with $50 \%$ of gravel content was chosen as indicative of the field conditions. Using Fig 18, the shear strength parameter values of the debris with 50\% gravel content were established as $\phi=46^{\circ}$ and $c=41$ to $71 \mathrm{kPa}$. The soil at the site was classified as sandy gravels, and so the shear-strength parameter values appear to be on the high side, although they are within the range suggested by Duncan and Christopher (2004) and the friction angle range of $40^{\circ}$ to $50^{\circ}$ for coarse granular material suggested by Terzaghi et al. (1996). Wang et al. (2017) performed laboratory investigations on gravelly calcareous soil that were found to exhibit a high cohesion and a larger friction angle than other granular materials. In the present case, the XRD results for the debris material reveal that calcium carbonate and clay 
minerals are predominant. The calcareous effect significantly controls inter-grain bonding between the gravel and sand-fines matrix. As a result, the strata encountered at the site was hard with a considerable amount of cohesion. Therefore, revised shear-strength parameters $\mathrm{c}$ in the range of 41 to $71 \mathrm{kPa}$ and $\phi$ equal to $46^{\circ}$ obtained through the parametric analysis were considered as reasonable.

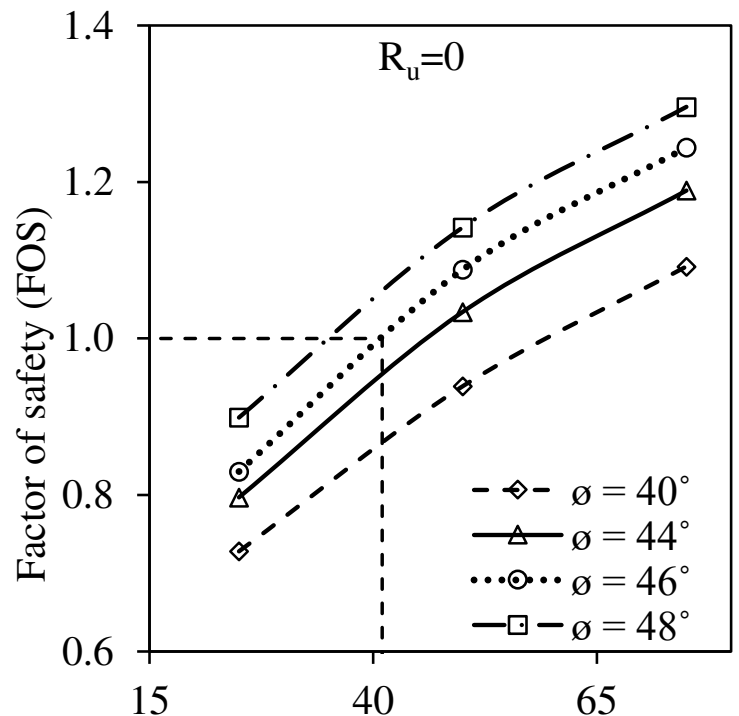

Cohesion, $\mathrm{kPa}$

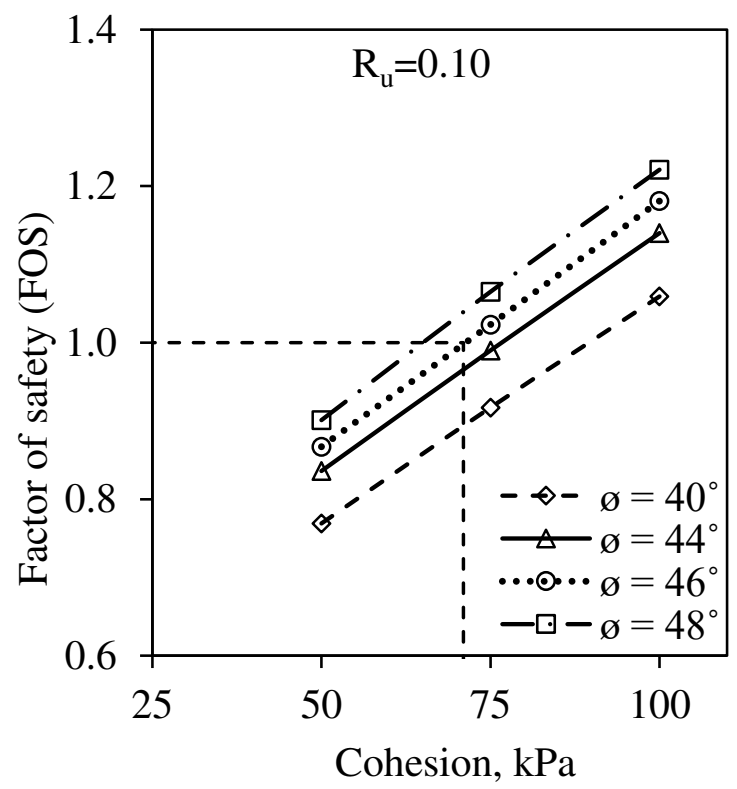

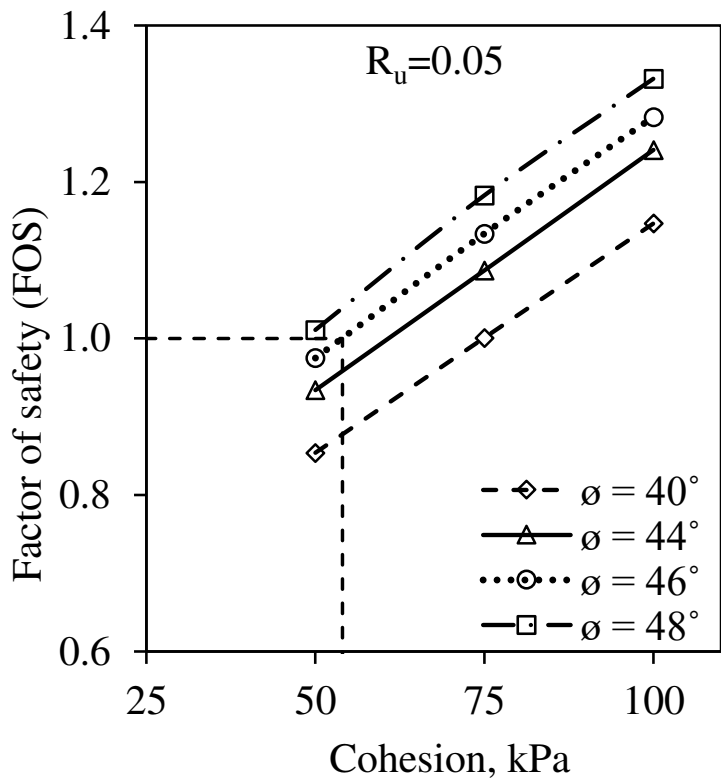

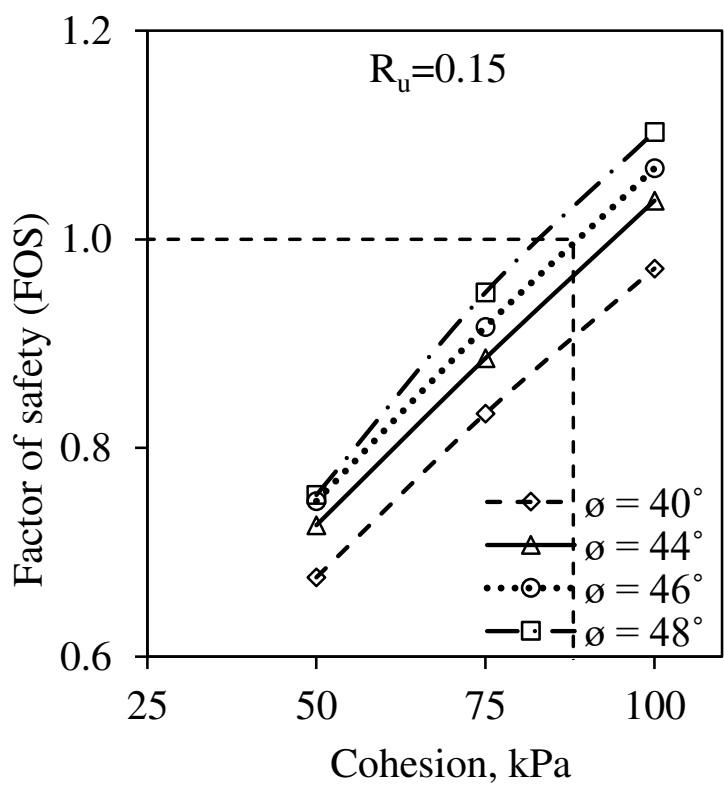

Fig. 18 Results of parametric analyses performed for $\mathrm{R}_{\mathrm{u}}=0,0.05,0.1$ and 0.15

Stability analysis was now carried out under different conditions, i.e. dry static, dry-seismic, saturated static and saturated-seismic. Seismic coefficients $\alpha_{\mathrm{h}}=0.15$ and $\alpha_{\mathrm{v}}=0.10$ were used in the seismic analysis, the results of which are summarised in Table 5. The results of stability analysis wth $\mathrm{c}=41 \mathrm{kPa}$ indicate that slope is found to be in limiting state even in the dry state and becomes unstable under saturated state. However, it is anticipated that no such noticeable slips observed at the landslide site over a period of nearly 4 years. Therefore, the value of cohesion close to $71 \mathrm{kPa}$ is more representative to true field conditions of the slope. The findings with $\mathrm{c}=71 \mathrm{kPa}$ indicate 
that under dry conditions, the slope is stable with FOS $=1.21$. For $R_{u}=0.1$, the value of FOS was reduced to 1.0 . With seismic loading, FOS was 0.94 and 0.77 under dry and saturated conditions, respectively. This indicates that the slope is stable under dry conditions, but as the pore water pressure builds up in the slope mass, the slope reaches the limiting state, in which slope failure is likely to occur. It is a well-known fact that pore water pressure that develops due to rainfall will have a significant effect on landslide stability (Bizjakand Zupancic 2009; Bednarczyk 2018). Moreover, the slope will be unstable in the rare case of it experiencing a seismic load.

Table 5 FOS of slope for various conditions

\begin{tabular}{|c|c|}
\multicolumn{2}{c}{$\left(\mathrm{c}=41\right.$ to $\left.71 \mathrm{kPa}, \phi=46^{\circ}\right)$} \\
\hline Condition & The factor of safety (FOS) \\
\hline Dry static & $1.01-1.32$ \\
\hline Dry seismic & $0.79-1.03$ \\
\hline Saturated static & $0.77-1.00$ \\
\hline Saturated seismic & $0.6-0.77$ \\
\hline
\end{tabular}

After the rainfall in 2016, distress was observed in the slope due to infiltration of water into the slope mass, after which a new scarp was identified (Fig. 2). This indicates that the FOS of the slope in the saturated state was nearly 1. Pore water pressure develops due to heavy rainfall and will have a significant effect on landslide stability. Hence, efforts should be made to keep the slope drained and dry by providing a proper surface drainage system. Moreover, some protection measures such as nailing may be provided.

\section{Conclusions}

Assessing satability state of a landslide site in Himalayan region is one of major concern due to uncertinities in proportion of large size particles in the debris material and pore water pressure variations. Incorrect inputs of shear strength paraneters and pore water pressure to a stability analysis wrongly interpret the stability state of the landslide site. Consequently, sudden surprises occur in the form of hazards that leads to lost of property and lifes. This could be overwhelmed by perfoming large size shear tests on debris material followed by field investigations to get the shear strength parameters representat to true field conditions. Therefore in the present study, experimental and field investigation study of a Surbhi Resort landslide site followed by stability analysis was undertaken. It has been concluded that

i. The kinematic analysis revealed the possibility of toppling failure at the crown of the landslide site.

ii. Field investigation by a GPR survey indicated sinking zone, disturbed/subsided strata beneath the new scarp.

iii. Results of XRD analysis indicated that the debris material at the site are gravelly and calcareous deposits.

iv. A substantial increase in friction angle was noticed with increasing gravel content in the debris material. As the pore water pressure is one of the parameters which is unknown in the filed, back analysis was perfomed to adopt shear strength parameteters. The shear strength parameters of debris material are estimated to be $\phi$ $=46^{\circ}$ and $\mathrm{c}=41$ to $71 \mathrm{kPa}$.

v. Using representative shear-strength parameters, stability analyses of the slope were carried out for dry, dryseismic, saturated and saturated-seismic conditions using shear-strength parameters obtained from the back-analysis. FOS values were 1.2 and 1.0 for the dry and saturated states, respectively, and these values were decreased by seismic loading. Based on the stability analysis, it can be concluded that the slope is marginally stable, but failure is likely to occur due to pore water pressure build-up in the geomaterials. 
Based on the the present study, it was established that the new scarp that developed during 2016 was due to the ingress of water into the geomaterials. Hence, a proper drainage system should be instigated to arrest/minimise the ingression of water into the slope mass. Furthermore, nailing should be carried out at places where subsiding in layers (i.e., disturbed strata) was observed, to reinforce and strengthen the disturbed strata.

\section{Acknowledgment}

The authors thank the institute National Geotechnical Facility (NGF), Dehradun for availing some of the facilities used in the present study. The authors also thank to Dr. Ruchika Tandon, who assisted during field investigations. Help received by Er. Manojit Samanta, Scientist, CSIR - Central Building Research Institute (CBRI), Roorkee is also thankfully acknowledged. Special thanks are due to research scholars and laboratory staffs of NGF and Geotechnical Engineering at IIT Roorkee for the co-operation and support. 


\section{References}

Asef MR, Reddish DJ, Lloyd PW (2000) Rock-support interaction analysis based on numerical modelling Geotech. Geol Eng18(1):23-37. (View via CrossRef)

Aydan O, Ulusay R, Kawamoto T (1997) Assessment of rock massstrength for underground excavations. In: Proceedings of the $36^{\text {th }}$ US rock mechanics symposium, New York, June/July 1997, pp 777-786. (View via CrossRef)

Aydan O, Dalgic S (1998) Prediction of deformation behaviour of 3 lane Bolu tunnel through squeezing rock of north Anatolian fault zone (NAFZ). In: Proceedings of regional symposium on sedimentary rock engineering Taipei; 1998 p 228-233. (Google scholar)

Barton N (1976) The shear strength of rock and rock joints. International Journal of Rock Mechanics and Mining Sciences and Geomechanics Abstracts 13(9):255-79. (View via CrossRef)

Barton N (2002) Some new Q-Value correlations to assist in site characteristics and tunnel design. Int J Rock Mech Min Sci 39:185-216. (View via CrossRef)

Barton NR, Lien R, Lunde J (1974) Engineering classification of rock masses for the design of tunnel support. Rock mechanics Volume 6 Issue 4 pp 189-236. (Google scholar)

Batayneh A, Abueladas A, Moumani K (2002) Use of Ground-Penetrating Radar for Assessment of Potential Sinkhole Conditions: An Example from Ghor al Haditha Area Jordan. Environmental Geology 41 977-983. (View via CrossRef)

Bednarczyk Z (2018) Identification of flysch landslide triggers using conventional and 'nearly real-time' monitoring methods - An example from the Carpathian Mountains Poland. Engineering Geology244 41-56. (View via

$\underline{\text { CrossRef) }}$

Bizjak KF, Zupancic A (2009) Site and laboratory investigation of the Slanoblato landslide. Engineering Geology 105 171-185 (View via CrossRef)

Deere DU (1963) Technical Description of Rock Cores for Engineering Purpose. Rock Mechanics and Engineering Geology Vol 1 No 1 pp 17-22. (Research article)

Dudeja D, Bhatt SP, Biyani AK (2017) Stability assessment of slide zones in Lesser Himalayan part of Yamunotri pilgrimage route, Uttarakhand, India. Environmental Earth Sciences volume 76, Article number: 54.(View via CrossRef)

Duncan CW, Christopher WM (2004) Rock slope engineering civil and mining, 4th edition. Spon press Taylor and Francis Group, London and Newyork. (Google scholar)

Dupla JC, Pedro LS, Canou J, Dormieux L (2007) Mechanical behaviour of coarse-grained soil reference. Bull Lab PontsChaussees 268-269:1-58(N1):1-58. (Research article)

Gupta V, Iqrar A (2007) Geotechnical estimation of Surabhi Resort landslide in Mussoorie Garhwal. Himalayas India Himalayan Geol 28(2):21-32. (ResearchGate)

Gupta V, Rajinder KB, Amir MK, Vipin K, Saini AS, Tandon RS, Thomas P (2016) Finite element analysis of failed slope by shear strength reduction technique: a case study for Surabhi Resort Landslide Mussoorie township Garhwal Himalaya. Geomatics Natural Hazards and Risk Vol 7 No 5 1677-1690. (View via CrossRef)

Hoek E (1994) Strength of rock and rock masses. ISRM News J, 2(2), 4-16. (Google scholar)

Hoek E, Brown ET (1980) Empirical strength criterion for rock masses. J Geotech Geoenviron Eng;106 (9):101335. (Google scholar)

Hoek E, Brown ET (2018) The HoekeBrown failure criterion and GSI e 2018 edition. Journal of Rock Mechanics and Geotechnical Engineering xxx , 1-19. (View via CrossRef)

Hoek E, Carranza TC, Corkum B (2002) Hoek-Brown failure criterion-2002 edition. In: Proceedings of NARMSTAC Conference 2002; Toronto: University of Toronto p 267-73. (Google scholar)

Iannacchione AT, Vallejo LE (2000) Shear Strength Evaluation of Clay-Rock Mixtures Slope Stability 2000 Proceedings of Sessions of Geo-Denver 2000 Denver Colorado August 5-8 Geotechnical Special Publication No 
101 Editors; Griffiths D V Fenton G A and Martin T R Reston VA: American Society of Civil Engineers 209-223. (ResearchGate)

IS: 2720-Part 4 (1985) Indian standard methods of test for soils: Grain size analysis. BIS, New Delhi. (Google scholar)

Irfan TY, Tang KY (1993) Effect of the Coarse Fractions on the Shear Strength of Colluvium. Special Project Report SPR 15/92 (GEO 23) Hong Kong pp 223. (Google scholar)

Kalamaras GS, Bieniawski ZT (1995) A rock mass strength concept for coal seams incorporating the effect of time In: Proceedings of 8th ISRM congress(Tokyo Japan), Balkema pp 295-302. (ResearchGate)

Li Y (2013) Effects of particle shape and size distribution on the shear strength behaviour of composite soils. Bulletin of Engineering Geology and the Environment volume 72 371-381. (View via CrossRef)

Lindquist ES (1994) The strength and deformation properties of melange: Ph.D. Dissertation; Dept. of Civil Engineering, Univ. California at Berkeley, California, 262 p.; publ. UMI, Inc., Ann Arbor, Michigan. (Google scholar)

Malik JN, Mohanty C (2007) Active tectonic influence on the evolution of drainage and landscape: Geomorphic signatures from frontal and hinterland areas along the Northern Himalaya India. Jour Asian Earth Sci v29 (5-6) pp 604-618. (View via CrossRef)

Medley E (1999) Systematic characterization of mélange bimrocks and other chaotic soil rock mixtures. Felsbau Rock Soil Engg. 17 (3): 152-62.(Google scholar)

Potro RD, Hurlimann M (2008) Geotechnical classification and characterisation of materials for stability analyses of large volcanic slopes. Engineering Geology 98 1-17. (View via CrossRef)

Ramamurthy T (1986) Stability of rock masses. Ind Geotech Journal 16(1):1-74 9. (Google scholar)

Ramamurthy T, Rao GV, Rao KS (1985) A strength criterion for rocks. In: Proceedings of Indian geotechnical conference p 59-64. (Google scholar)

Rocscience Inc. (2005) Phase2 v6.0 - a two-dimensional finite element analysis program.

Sheorey PR, Biswas AK, Choubey VD (1989) An empirical failure criterion for rocks and jointed rock masses. EngGeol 26:141-59. (View via CrossRef)

Siddique T, Pradhan SP (2018) Stability and sensitivity analysis of Himalayan road cut debris slopes: an investigation along NH-58 India. Nat Hazards 93:577-600. (View via CrossRef)

Singh B, Goel RK (1999) Rock mass classifications - a practical approach in civil engineering. 1st ed Amsterdam: Elsevier Ltd. (Google scholar)

Singh B, Villadkar MN, Samadhiya NK, Mehrotra VK (1997) Rock mass strength parameters mobilised in tunnels. TunnUndergr Space Technol12 (1):47-54. (View via CrossRef)

Singh M, Pandit K, Shaunik D (2015) Some aspects of geotechnical investigations at Surbhi landslide Mussoorie. In: Proceeding of 50th Indian Geotechnical Conference. (Google scholar)

Singh M, Singh B (2005) A Strength Criterion Based on Critical State Mechanics for Intact Rocks, Rock Mech \& Rock Engg , 38 (3), 243-248. (View via CrossRef)

Singh M, Singh B (2012) Modified Mohr-Coulomb criterion for non-linear triaxial and polyaxial strength of jointed rocks. Int J Rock Mech Min Sci 51 43-52. (View via CrossRef)

Terzaghi K, Peck RB, Mesri G (1996) Soil Mechanics in Engineering Practice, John Wiley and Sons, Inc., New York, NY.(Google scholar)

Tewari VC (2012) Neoproterozoic Blaini glacial diamictite and Ediacaran Krol carbonate. Geological Society London Special Publications 366(1):265-276. (ResearchGate)

Trueman R (1988) An evaluation of strata support techniques in dual life gate roads Cardiff: University of Wales. (Google scholar)

Varnes DJ (1958) Landslides types and processes In Eckel E B (ed) Landslides and Engineering Practice Special Report 29 NAS-NRC Publication 544 Washington DC: Highway Research Board 20-47. (Article link) 
Wan Y, Kwong J (2002) Shear strength of soils containing amorphous clay-size materials in a slow-moving landslide. Engineering Geology 65 293-303. (View via CrossRef)

Wang Y, Feng WK, Li CH, Hou ZQ (2020) An investigation into the effects of block size on the mechanical behaviors of bimsoils using variable-angle shear experiments. Environmental Earth Sciences volume 79, Article number: 69.(View via CrossRef)

Wang XZ, Wang X, Jin ZC, Meng QS, Zhu CQ, Wang R (2017) Shear characteristics of calcareous gravelly soil. Bulletin of Engineering Geology and the Environment volume 76 pages561-573. (View via CrossRef)

Wolf L, Collier J, Tuttle M, Bodin P (1998) Geophysical Reconnaissance of Earthquake-Induced Liquefaction Features in the New Madrid Seismic Zone. Journal of Applied Geophysics 39 (3)121-129. (Google scholar)

Xu WJ, Xu Q RL (2011) Study on the shear strength of soil-rock mixture by large scale direct shear test. International Journal of Rock Mechanics and Mining Sciences 48 (8) 1235-1247. (Article link)

Yudhbir WL, Prinzi F (1983) An empirical failure criterion for rock masses. In:Proceedings of 5th international congress on rock mechanics Madras pB1-B8. (Google scholar)

Zhang L (2010) Estimating the strength of jointed rock masses. Rock Mech Rock Eng43(4):391-402. (View via CrossRef) 


\section{Supplementary Files}

This is a list of supplementary files associated with this preprint. Click to download.

- Highlights.docx 